\title{
Sebaran spesies dan status kerapatan ekosistem mangrove di pesisir Kabupaten Muna Barat, Sulawesi Tenggara
}

\section{Distribution of species and density status of mangrove ecosystems on the coast of West Muna Regency, Southeast Sulawesi}

\author{
Rahman $^{\mathrm{a}}$, Yusli Wardiatno ${ }^{\mathrm{bc}}$, Fredinan Yulianda ${ }^{\mathrm{b}}$, Iman Rusmana $^{\mathrm{d}}$ \\ ${ }^{\text {a }}$ Program Doktor Pengelolaan Sumberdaya Pesisir dan Lautan, Sekolah Pascasarjana, Institut Pertanian Bogor, Kampus IPB \\ Darmaga Bogor, 16680, Indonesia [+62 82193576093] \\ ${ }^{\mathrm{b}}$ Departemen Manajemen Sumberdaya Perairan, Fakultas Perikanan dan Ilmu Kelautan, Institut Pertanian Bogor, Kampus IPB \\ Darmaga Bogor, 16680, Indonesia \\ ${ }^{\mathrm{c}}$ Pusat Penelitian Lingkungan Hidup, Institut Pertanian Bogor, Kampus IPB Darmaga Bogor, 16680, Indonesia \\ ${ }^{d}$ Departemen Biologi, Fakultas Matematika dan Ilmu Pengetahuan Alam, Institut Pertanian Bogor, Kampus IPB Darmaga Bogor, \\ 16680, Indonesia
}

\section{Article Info:}

Received: 25 - 03 - 2020

Accepted: $26-06-2020$

Keywords:

Coastal area, mangrove conversion, species distribution, Sulawesi

Corresponding Author:

Yusli Wardiatno

Departemen Manajemen

Sumberdaya Perairan, Fakultas

Perikanan dan Ilmu Kelautan,

Institut Pertanian Bogor;

Tel. +628128608966

Email:

yusli@apps.ipb.ac.id

\begin{abstract}
Mangrove ecosystem is valuable coastal ecosystems for human because its economic, physical and ecological functions. One of the coastal areas which is the habitat of the mangrove ecosystem is the coast of West Muna Regency. The coastal development in the coastal area had reduced the mangrove area and the density of mangrove ecosystem, which in turn affected the structure and density status of the ecosystem. This study aimed to analyze the distrubtion of species and the status of mangrove density on the coast of West Muna Regency. The result shows that the number of mangrove species in the coast of West Muna Regency was ten species consisting of B. cylindrica, B. gymnorrhiza, R. mucronata, R. apiculata, R. stylosa, S. alba, X. granatum, C. tagal, S. hydrophyllacea, and $\mathrm{C}$. inophyllum. The total density of mangrove was 752 trees/ha, however, by seeing in detail through each sampling station the density of Station I, II, III and IV was 879, 621, 687 and 820 trees/ha, respectively. Those densities are categorized as low density.
\end{abstract}

How to cite (CSE Style $8^{\text {th }}$ Edition):

Rahman, Wardiatno Y, Yulianda F, Rusmana I. 2020. Sebaran spesies dan status kerapatan ekosistem mangrove di pesisir Kabupaten Muna Barat, Sulawesi Tenggara. JPSL 10(3): 461-478. http://dx.doi.org/10.29244/jpsl.10.3.461-478.

\section{PENDAHULUAN}

Ekosistem mangrove adalah sekelompok pohon dan tumbuhan semak-semak yang hidup di habitat bakau yang berbeda satu dengan lainnya, tetapi mempunyai kesamaan adaptasi morfologi dan fisiologi terhadap habitat yang dipengaruhi oleh pasang surut yakni mangrove tergenang air laut pada saat pasang dan bebas dari genangan pada waktu surut (Kathiresan dan Bingham, 2001; Hogarth, 2007). Lebih lanjut, ekosistem mangrove merupakan ekosistem pesisir yang sangat penting bagi manusia karena memiliki fungsi ekonomi, fisik, dan ekologi. Fungsi ekonomi yaitu melalui pemanfaatannya sebagai kayu bakar, bahan bangunan, pewarna batik, dan obat-obatan. Fungsi fisik sebagai perangkap sedimen dan penahan ombak (Bengen, 2004; Martuti et al., 2018), dan fungsi ekologi yaitu sebagai daerah asuhan (nursery ground), pemijahan (spawning ground), dan mencari makan (feeding ground), serta mendukung kehidupan berbagai biota seperti ikan, udang, 
kepiting, kerang, dan biota lainnya (Woodroffe, 1982; Nordhaus et al., 2006; Hogarth, 2007; Abrantes dan Sheaves, 2009).

Salah satu wilayah pesisir yang merupakan habitat ekosistem mangrove adalah pesisir Pulau Muna (Rochmady, 2015) khususnya Kabupaten Muna Barat (Rahman et al., 2014). Menurut Rahman et al. (2014) terdapat 7 spesies mangrove yang dominan di wilayah pesisir Kabupaten Muna Barat yaitu B. cylindrica, $B$. gymnorrhiza, $R$. apiculata, $R$. mucronata, $R$. stylosa, S. alba, dan X. granatum dengan total kerapatan berkisar pada 1000 hingga 1500 pohon/ha dan berada pada kategori sedang menurut Rahman et al. (2019). Spesiesspesies tersebut tersebar dan membentuk sistem zonasi menurut perbedaan substrat. $B$. cylindrica, $B$. gymnorrhiza, $R$. apiculata, dan $R$. mucronata dominan terdapat pada habitat lumpur, $R$. stylosa dan $X$. granatum dominan pada habitat lumpur berpasir, sedangkan $S$. alba dominan pada habitat pasir berlumpur (Rahman et al., 2014).

Pada tahun 2016 sampai dengan 2017, Kabupaten Muna Barat melaksanakan proyek pembangunan tambak seluas 100 ha di kawasan pesisir Kabupaten Muna Barat. Proyek tersebut berdampak pada pengurangan luas dan kerapatan ekosistem mangrove sehingga mempengaruhi struktur dan status kerapatan ekosistem mangrove. Hal ini menunjukkan bahwa ekosistem mangrove memiliki nilai kepekaan lingkungan baik secara sosial maupun ekologi (Danipranata et al., 2019). Lebih lanjut, Rahman et al. (2020) menjelaskan penurunan luas dan kerapatan ekosistem mangrove di pesisir Muna Barat juga disebabkan oleh adanya pembangunan tambak, dermaga, jalan, dan pemukiman. Berdasarkan hal tersebut, maka penelitian ini dilakukan dengan tujuan untuk menganalisis sebaran dan status kerapatan ekosistem mangrove di pesisir Kabupaten Muna Barat sehingga dapat dijadikan sebagai dasar dalam pengambilan kebijakan pengelolaan ekosistem mangrove.

\section{METODE}

\section{Lokasi dan Waktu Penelitian}

Penelitian ini dilakukan pada Januari sampai dengan Desember 2019 di empat wilayah yang merupakan ekosistem mangrove. Ada empat wilayah yang dijadikan stasiun pengamatan, yaitu Kecamatan Maginti (stasiun I), Kecamatan Tiworo Tengah (stasiun II), Kecamatan Tiworo Kepulauan (stasiun III), dan Kecamatan Sawerigadi (stasiun IV), Kabupaten Muna Barat (Gambar 1).

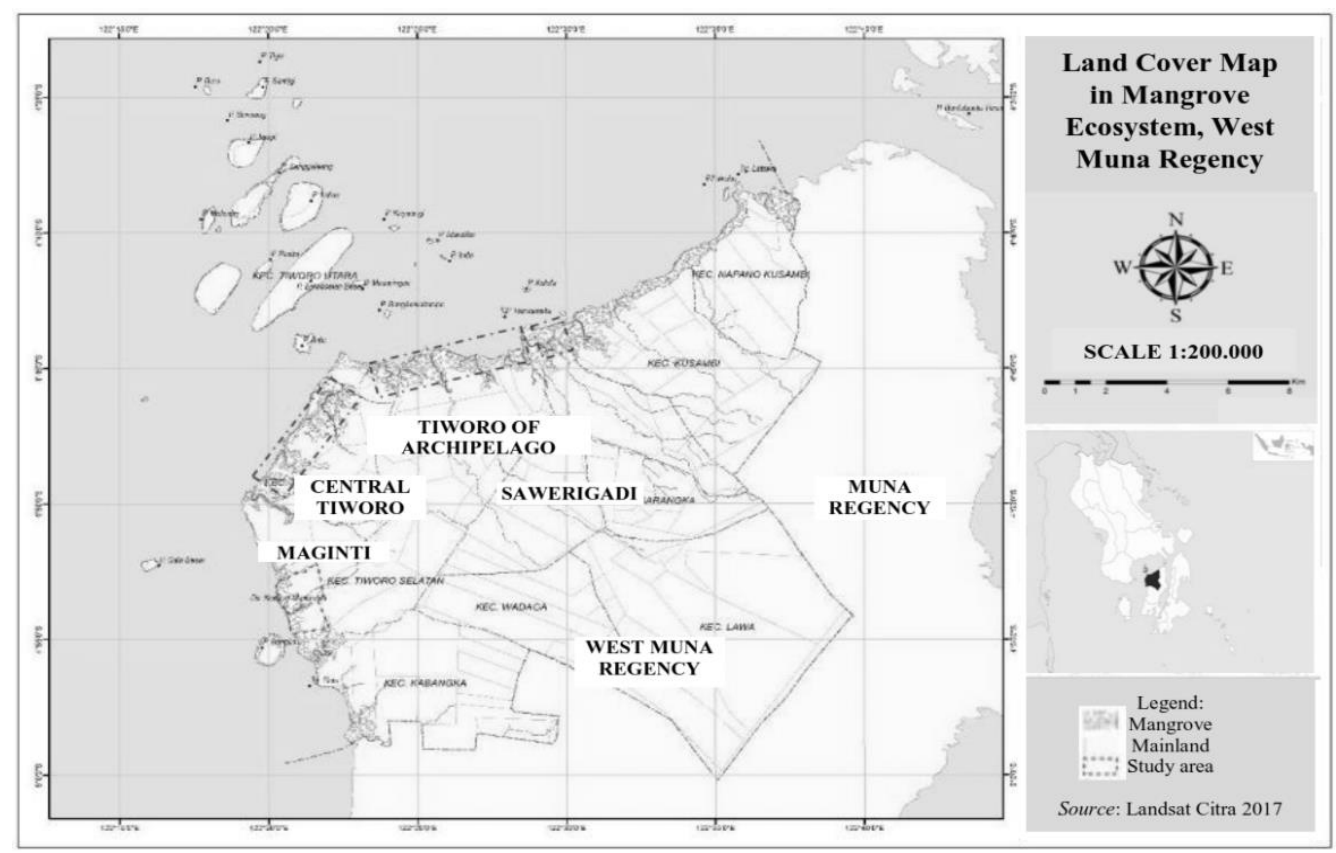

Gambar 1 Lokasi penelitian eksosistem mangrove di pesisir Kabupaten Muna Barat, Sulawesi Tenggara 462 


\section{Metode Pengumpulan Data}

Pengumpulan data kerapatan mangrove dilakukan dengan menggunakan plot $10 \times 10 \mathrm{~m}^{2}$ baik pada kategori pohon maupun semai. Plot diletakkan pada transek garis sepanjang $100 \mathrm{~m}$ (Gambar 2). Total transek garis yaitu 30 dengan rincian $6,11,9$, dan 4 transek pada masing-masing stasiun I, II, III, dan IV, sehingga total plot yang digunakan adalah 300 plot.

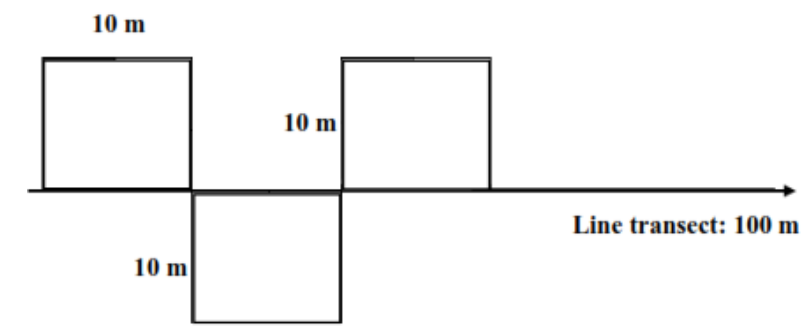

Gambar 2 Kerangka plot pengukuran kerapatan mangrove pada penelitian ekosistem mangrove di pesisir Kabupaten Muna Barat, Sulawesi Tenggara

\section{Metode Analisis Data}

Setelah data ekosistem mangrove didapatkan, selanjutnya dilakukan analisis data untuk mengetahui struktur dan status ekosistem mangrove. Selain itu, analisis indeks nilai (INP) penting juga dilakukan terhadap mangrove kategori pohon pada tiap spesies mangrove. Persamaan untuk memperoleh INP mangrove yaitu sebagai berikut (Kusmana, 1997):

INP $=$ Kerapatan Relatif (KR) + Frekuensi Relatif $(F R)+$ Dominansi Relatif (DR)

$\mathrm{K}($ pohon $/$ ha $)=\frac{\Sigma \text { pohon suatu spesies }}{\text { Luas area }}$

$\mathrm{KR}(\%) \quad=\frac{\text { Kspesies ke- } \mathrm{i}}{\text { Ktotal }} \times 100$

F $\quad=\frac{\text { Jumlah plot ditemukan suatu jenis }}{\text { Total plot }}$

FR $(\%) \quad=\frac{\text { Frekuensi suatu jenis }}{\text { Frekuensi total }} \times 100$

Di $\quad=\frac{\text { Luas basal area suatu jenis }}{\text { Luas total }}$

Dt $=\frac{\text { Luas basal area semua jenis }}{\text { Luas total }}$

DR $=\frac{\text { Dominasi suatu jenis }}{\text { Dominasi semua jenis }} \times 100$

Status kerapatan mangrove diklasifikasi menjadi lima kategori dengan mengacu pada kriteria menurut Rahman et al. (2019) seperti pada Tabel 1 berikut:

Tabel 1 Kriteria kerapatan mangrove kategori pohon (Rahman et al., 2019)

\begin{tabular}{|c|c|c|}
\hline Kerapatan (pohon/ha) & Warna & Kriteria \\
\hline$<500$ & & Sangat rendah \\
\hline$>500-1000$ & & Rendah \\
\hline$>1000-1500$ & & Sedang \\
\hline$>1500-2000$ & & Padat \\
\hline$>2000$ & & Sangat padat \\
\hline
\end{tabular}




\section{HASIL DAN PEMBAHASAN}

\section{Sebaran Spesies Mangrove}

Berdasarkan hasil identifikasi spesies dengan mengacu pada Noor et al. (2006) didapatkan bahwa terdapat sepuluh spesies mangrove di pesisir Kabupaten Muna Barat. Masing-masing spesies tersebar pada 4 stasiun yaitu spesies B. cylindrica, B. gymnorrhiza, R. mucronata, R. apiculata, $R$. stylosa, S. alba pada stasiun I dan III, 7 spesies pada stasiun II yaitu B. cylindrica, B. gymnorrhiza, R. mucronata, $R$. apiculata, $R$. stylosa, $S$. $a l b a$, dan $X$. granatum, serta 9 spesies pada stasiun IV yaitu B. cylindrica, B. gymnorrhiza, $R$. mucronata, $R$. apiculata, R. stylosa, S. alba, C. tagal, S. hydrophyllacea, dan C. inophyllum (Tabel 2).

Jumlah spesies tersebut lebih tinggi dibandingkan laporan Ledheng et al. (2009) di Tanjung Bastian NTT, Darmadi dan Ardhana (2010) di hutan mangrove Ngurah Rai, Imanuddin dan Simarangkir (2012) di Teluk Muara Badak, Auliyah dan Blongkod (2018) di Desa Dalapuli Barat, dan lebih rendah dibandingkan laporan Jamili et al. (2009) di Pulau Kaledupa, Ardiansyah et al. (2012) di Pulau Sebatik, dan Rizwany et al. (2016) di Pulau Sembilan.

Tabel 2 Sebaran spesies mangrove di pesisir Kabupaten Muna Barat

\begin{tabular}{lcccc}
\hline \multirow{2}{*}{ Spesies } & \multicolumn{3}{c}{ Sebaran } \\
\cline { 2 - 5 } & Stasiun I & Stasiun II & Stasiun III & Stasiun IV \\
\hline Bruguiera cylindrica & + & + & + & + \\
Bruguiera gymnorrhiza & + & + & + & + \\
Rhizophora apiculata & + & + & + & + \\
Rhizophora mucronata & + & + & + & + \\
Rhizophora stylosa & + & + & + & + \\
Sonneratia alba & + & + & + & + \\
Xylocarpus granatum & - & + & - & + \\
Ceriops tagal & - & - & - & + \\
Scyphiphora hydrophyllacea & - & - & - & + \\
Calophyllum inophyllum & - & - & - & 9 \\
\hline Total Spesies & 6 & 7 & 6 & + \\
\hline
\end{tabular}

Keterangan: $(+)=$ ada, $(-)=$ tidak ada

Hasil telaah dan kompilasi 161 literatur tahun 2005 sampai dengan 2020 (Tabel 3) terkait struktur komunitas mangrove menunjukkan bahwa terdapat 98 spesies mangrove di Indonesia yang terdiri dari 47 spesies mangrove utama dan 51 spesies mangrove asosiasi atau ikutan. Sebaran spesies mangrove tersebut yaitu 45 spesies di Papua, 34 spesies di Maluku, 36 spesies di Bali, 46 spesies di Nusa Tenggara, 63 spesies di Sulawesi, 54 spesies di Kalimantan, 59 spesies di Jawa, 43 spesies di Sumatera, dan 31 spesies di Riau (Tabel 4). Lebih lanjut, hasil telaah juga menunjukkan bahwa terdapat 1 spesies yang hanya ditemukan di wilayah Papua yaitu A. eucalyptifolia, 5 spesies hanya ditemukan di wilayah Kalimantan yaitu Cebera sp, Intsia bijuga, K. candel, O. tigillarium, dan X. mekongensis, 3 spesies hanya ditemukan di wilayah Nusa Tenggara yaitu $A$. spinosus, $C$. equisetifolia, dan $S$. grandifora, 7 spesies hanya ditemukan di wilayah di Sulawesi yaitu $A$. spinosus, C. odorata, Crassocephalum sp, G. ulmifolia, I. batatas, L. camara, dan S. foetida, 4 spesies hanya ditemukan di wilayah Jawa yaitu C. dactylon, P. karka, R. lamarckii, dan Scirpus sp, serta 2 spesies hanya ditemukan di wilayah Sumatera yaitu $C$. maritima dan M. citrifolia (Tabel 4). Selain itu terdapat 15 spesies yang ditemukan pada semua wilayah pesisir Indonesia yaitu A. corniculatum, A. alba, A. marina, B. gymnorrhiza, C. tagal, E. agallocha, I. pes-caprae, M. candidum, P. pinnata, R. apiculata, R. mucronata, $R$. stylosa, S. alba dan X. granatum (Tabel 4). 
Tabel 3 Daftar literatur terkait sebaran spesies mangrove di beberapa wilayah di Indonesia

\begin{tabular}{|c|c|}
\hline Lokasi & Sumber \\
\hline Papua & $\begin{array}{l}\text { Kusmana et al. (2003); Wambrauw dan Pattiasina (2005); Noor et al. (2006); Yewen et al. } \\
\text { (2008); Wibisono (2013); Katiandagho (2015); Masiyah dan Sunarni (2015); Mayor et al. } \\
\text { (2017); Hamuna dan Tanjung (2018); Alwi et al. (2019); Schaduw et al. (2019); Sunarni et } \\
\text { al. (2019) }\end{array}$ \\
\hline Maluku & $\begin{array}{l}\text { Noor et al. (2006); Suyadi (2009); Fuady et al. (2013); Ahmad (2015); Akbar et al. (2015) } \\
\text { Haya et al. (2015); Marcus dan Latupapua (2015); Akbar } \text { et al. (2016); Idrus (2016); } \\
\text { Madiama et al. (2016); Tolangara dan Ahmad (2017); Akbar } \text { et al. (2017); Tahir } \text { et al. } \\
\text { (2017); Akbar } \text { et al. (2018); Baksir et al. (2018); Lewerissa et al. (2018); Abubakar } \text { et al. } \\
\text { (2019) }\end{array}$ \\
\hline $\begin{array}{l}\text { Nusa } \\
\text { Tenggara }\end{array}$ & $\begin{array}{l}\text { Noor et al. (2006); Ledheng et al. (2009); Bessie et al. (2013); Hidayatullah dan Pujiono } \\
\text { (2014); Abo et al. (2015); Rita (2015); Rusydi et al. (2015); Imran dan Efendi (2016); } \\
\text { Anwar dan Mertha (2017); Zamroni (2017); Irwansah et al. (2019); Lapa dan Santoso } \\
\text { (2019); Seran (2019); Sani } \text { et al. (2019) }\end{array}$ \\
\hline Sulawesi & $\begin{array}{l}\text { Witjaksono (2002); Noor et al. (2006); Jamili et al. (2009); Kaunang dan Kimbal (2009); } \\
\text { Nauw (2012); Wahyuningsih et al. (2012); Putro (2013); Usman et al. (2013); Kontu } \\
\text { (2014); Rahman et al. (2014); Fakhrurrozy (2015); Rochmady (2015); Samsumarlin et al. } \\
\text { (2015); Tabba et al. (2015); Baderan (2016); Hartati dan Harudu (2016); Osmar (2016); } \\
\text { Sasauw et al. (2016); Annisa et al. (2017); Anthoni et al. (2017); Arifin (2017); Baderan } \\
\text { (2017); Haerul (2016); Lisna et al. (2017); Paruntu et al. (2017); Rahim et al. (2017); } \\
\text { Rahman et al. (2017); Saman (2017); Saru et al. (2017) Auliyah dan Blongkod (2018); } \\
\text { Momo dan Rahayu (2018); Rahim et al. (2018); Setiawan dan Mursidin (2018); Syahrial } \\
\text { (2018); Baderan (2019); Jacobs et al. (2019); Rahim dan Baderan (2019); Saru et al. (2019); } \\
\text { Rahman et al. (2020) }\end{array}$ \\
\hline Bali & $\begin{array}{l}\text { Noor et al. (2006); Darmadi dan Ardhana (2010); Hermawan et al. (2015); Wiyanto dan } \\
\text { Faiqoh (2015); Imamsyah (2017); Palguna et al. (2017); Andika et al. (2019) }\end{array}$ \\
\hline Kalimantan & $\begin{array}{l}\text { Noor et al. (2006); Rachmawani (2007); Ardiansyah et al. (2012); Imanuddin dan } \\
\text { Simarangkir (2012); Nurrahman et al. (2012); Ghufrona et al. (2015); Khairuddin (2016); } \\
\text { Irpan et al. (2017); Prastomo et al. (2017); Ratnasari et al. (2017); Wantoro et al. (2017); } \\
\text { Warsidi dan Endayani (2017); Marini et al. (2018); Kuncoro et al. (2019); Meidiana et al. } \\
\text { (2019); Muharamsyah et al. (2019); Rumalean } \text { et al. (2019) }\end{array}$ \\
\hline Jawa & $\begin{array}{l}\text { Setyawan et al. (2005); Agustianingsih (2006); Noor et al. (2006); Suryono (2006); Malik } \\
\text { (2011); Darmadi et al. (2012); Cahyanto dan Kuraesin (2013); Hastuti et al. (2013); Martuti } \\
\text { (2017); Susanto et al. (2013); Syawala (2013); Wicaksono (2014); Buwono et al. (2015); } \\
\text { Hilmi } \text { et al. (2015); Kusiani dan Sukanto (2015); Putri et al. (2015); Puspita (2015); } \\
\text { Ramdani } \text { et al. (2015); Supriadi et al. (2015); Wicaksono dan Muhdin (2015); Agustini et } \\
\text { al. (2016); Kusmana dan Ningrum (2016); Noveliyana (2016); Renta } \text { et al. (2016); Siska } \\
\text { (2016); Ula } \text { et al. (2016); Acik dan Sumardi (2017); Amaliyah (2017); Buwono (2017); } \\
\text { Poedjirahajoe } \text { et al. (2017); Pribadi } \text { et al. (2017); Syahrial } \text { et al. (2017); Ali } \text { et al. (2018); } \\
\text { Mughofar } \text { et al. (2018); Rahayu et al. (2018); Ashari } \text { et al. (2019); Tefarani } \text { et al. (2019); } \\
\text { Nopiana } \text { et al. (2020) }\end{array}$ \\
\hline Sumatera & $\begin{array}{l}\text { Noor et al. (2006); Susilo (2007); Fuady et al. (2013); Halawa et al. (2013); Afkar et al. } \\
\text { (2014); Mukhlisi et al. (2014); Hanggara (2016); Karnanda } \text { et al. (2016); Parmadi et al. } \\
\text { (2016); Rizwany et al. (2016); Theresia (2016); Zamdial (2016); Awn (2017); Mendrofa } \\
\text { (2017); Siringoringo et al. (2017); Febriansyah et al. (2018); Akhrianti et al. (2019) } \\
\text { Zamdial } \text { et al. (2019) }\end{array}$ \\
\hline
\end{tabular}




\begin{tabular}{ll}
\hline Lokasi & \multicolumn{1}{c}{ Sumber } \\
\hline Riau & Hamidi et al. (2002); Noor et al. (2006); Purba et al. (2013); Syahputra et al. (2013); \\
& Mariati (2016); Rivilgo et al. (2017); Sitinjak (2017); Pratama (2018); Syahrial et al. \\
& (2018); Irma et al. (2020)
\end{tabular}

Tabel 4 Sebaran spesies mangrove di beberapa wilayah di Indonesia

\begin{tabular}{|c|c|c|c|c|c|c|c|c|c|}
\hline Spesies & Papua & Maluku & $\begin{array}{c}\text { Nusa } \\
\text { Tenggara }\end{array}$ & Sulawesi & Bali & Kalimantan & Jawa & Sumatera & Riau \\
\hline Acrostichum aureum & & & + & + & + & + & + & + & \\
\hline Acrostichum speciosum & & & & + & & & + & + & + \\
\hline Acanthus ebracteatus & + & & & & & + & & & \\
\hline Acanthus ilicifolius & + & & + & + & + & + & + & + & + \\
\hline Acanthus spinosus & & & & + & & & & & \\
\hline Aegiceras floridum & + & + & & + & & + & + & + & \\
\hline Aegialitis annulata & + & & + & & & & & & \\
\hline Aegiceras corniculatum & + & + & + & + & + & + & + & + & + \\
\hline Amaranthus spinosus & & & + & & & & & & \\
\hline Amyema anisomeres & & & & & & + & & & \\
\hline Amyema gravis & & & & & & + & + & & \\
\hline Amyema mackayense & + & & & & & & & & \\
\hline Avicennia alba & + & + & + & + & + & + & + & + & + \\
\hline Avicennia eucalyptifolia & + & & & & & & & & \\
\hline Avicennia lanata & & & + & + & + & + & & + & + \\
\hline Avicennia marina & + & + & + & + & + & + & + & + & + \\
\hline Avicennia officinalis & + & + & + & + & & + & + & + & + \\
\hline Avicennia rumphiana & & & & & & + & & & + \\
\hline Barringtonia asiatica & & & + & & + & & + & & + \\
\hline Bruguiera cylindrica & + & + & & + & & + & + & + & + \\
\hline Bruguiera exaristata & + & + & & + & & & & & \\
\hline Bruguiera gymnorrhiza & + & + & + & + & + & + & + & + & + \\
\hline Bruguiera hainesii & + & & & + & & + & & + & \\
\hline Bruguiera parviflora & + & & + & + & & + & & & \\
\hline Bruguiera sexangula & + & + & & + & & + & + & & \\
\hline Camptostemon schultzii & & + & & & & + & & & \\
\hline $\begin{array}{l}\text { Camptostemon } \\
\text { philippinense }\end{array}$ & & & & + & & + & & & \\
\hline Calophyllum inophyllum & & & & + & + & & + & & \\
\hline Calotropis gigantea & & & + & + & + & & + & & \\
\hline Canavalia maritima & & & & & & & & + & \\
\hline Casuarina equisetifolia & & & + & & & & & & \\
\hline Cerbera sp & & & & & & + & & & \\
\hline Cerbera manghas & & & + & + & + & + & + & & \\
\hline Ceriops decandra & + & + & + & + & & + & + & + & + \\
\hline Ceriops tagal & + & + & + & + & + & + & + & + & + \\
\hline Ceriops zippeliana & & + & & & & & & & \\
\hline Chromolaena odorata & & & & + & & & & & \\
\hline Cyperus malaccensis & & & & & & & + & + & \\
\hline Cynodon dactylon & & & & & & & + & & \\
\hline
\end{tabular}




\begin{tabular}{|c|c|c|c|c|c|c|c|c|c|}
\hline Spesies & Papua & Maluku & $\begin{array}{c}\text { Nusa } \\
\text { Tenggara }\end{array}$ & Sulawesi & Bali & Kalimantan & Jawa & Sumatera & Riau \\
\hline Clerodendrum inerme & + & & & & + & & + & & \\
\hline Crassocephalum sp & & & & + & & & & & \\
\hline Derris trifoliata & & + & + & + & + & + & + & + & \\
\hline $\begin{array}{l}\text { Dolichandrone } \\
\text { spathacea }\end{array}$ & & & + & + & & + & & & \\
\hline Excoecaria agallocha & + & + & + & + & + & + & + & + & + \\
\hline Ficus microcarpa & & & & + & & & + & & \\
\hline Fimbristylis ferruginea & & & & + & & & + & + & \\
\hline Finlaysonia maritima & & & & & + & & + & & \\
\hline Guazuma ulmifolia & & & & + & & & & & \\
\hline Gymnanthera paludosa & + & & & + & + & & + & & \\
\hline Heritiera globosa & & & & + & & + & & & \\
\hline Heritiera littoralis & & + & + & + & & + & + & & \\
\hline Hibiscus tiliaceus & + & & + & & + & + & + & + & + \\
\hline Intsaa bijuga & & & & & & + & & & \\
\hline Ipomoea batatas & & & & + & & & & & \\
\hline Ipomoea pes-caprae & + & + & + & + & + & + & + & + & + \\
\hline Kandelia candel & & & & & & + & & & \\
\hline Lantana camara & & & & + & & & & & \\
\hline Lumnitzera littorea & + & + & & + & & + & & + & + \\
\hline Lumnitzera racemosa & + & + & + & + & + & + & & + & \\
\hline Melastoma candidum & + & + & + & + & + & + & + & + & + \\
\hline Morinda citrifolia & & & & & & & & + & \\
\hline Nypa fruticans & + & + & + & + & + & + & + & + & + \\
\hline Oncosperma tigillarium & & & & & & + & & & \\
\hline Osbornia octodonta & + & + & + & & & & + & & \\
\hline Pandanus odoratissima & + & & & + & + & + & + & + & \\
\hline Pandanus tectorius & + & + & & + & & + & + & + & + \\
\hline Passiflora foetida & + & + & + & + & + & + & + & + & + \\
\hline Paspalum spp & & & & + & & & + & & \\
\hline Pemphis acidula & & & + & + & & & + & & \\
\hline Phragmites karka & & & & & & & + & & \\
\hline Pongamia pinnata & + & + & + & + & + & + & + & + & + \\
\hline Rhizophora apiculata & + & + & + & + & + & + & + & + & + \\
\hline Rhizophora lamarckii & & & & & & & + & & \\
\hline Rhizophora mucronata & + & + & + & + & + & + & + & + & + \\
\hline Rhizophora stylosa & + & + & + & + & + & + & + & + & + \\
\hline Ricinus communis & & & + & + & & & & & \\
\hline Sarcolobus globosa & & & & & & & + & & \\
\hline Scaevola taccada & + & + & & + & & & + & + & + \\
\hline Scirpus sp & & & & & & & + & & \\
\hline $\begin{array}{l}\text { Scyphiphora } \\
\text { hydrophyllacea }\end{array}$ & + & & + & + & & + & & + & + \\
\hline $\begin{array}{l}\text { Stachytarpheta } \\
\text { jamaicensis }\end{array}$ & + & & & + & + & + & + & & \\
\hline Sesbania grandiflora & & & + & & & & & & \\
\hline Sesuvium portulacastrum & & + & + & + & + & & + & + & \\
\hline
\end{tabular}




\begin{tabular}{|c|c|c|c|c|c|c|c|c|c|}
\hline Spesies & Papua & Maluku & $\begin{array}{c}\text { Nusa } \\
\text { Tenggara }\end{array}$ & Sulawesi & Bali & Kalimantan & Jawa & Sumatera & Riau \\
\hline Sonneratia alba & + & + & + & + & + & + & + & + & + \\
\hline Sonneratia caseolaris & & & + & + & + & + & + & + & + \\
\hline Sonneratia ovata & & & & & & + & & + & \\
\hline Spinifex littoreus & & & + & + & & & + & & \\
\hline Sterculia foetida & & & & + & & & & & \\
\hline Terminalia catappa & + & + & + & + & & + & + & + & + \\
\hline Thespesia populnea & + & & + & + & + & + & + & + & \\
\hline Vigna marina & & & + & & & & & & \\
\hline Vitex ovata & & & + & & + & & + & & \\
\hline Wedelia biflora & + & & + & + & & + & + & & \\
\hline Xylocarpus granatum & + & + & + & + & + & + & + & + & + \\
\hline Xylocarpus moluccensis & + & + & + & + & + & + & + & + & \\
\hline Xylocarpus mekongensis & & & & & & + & & & \\
\hline Xylocarpus rumphii & + & & & & & & + & & \\
\hline Total & 45 & 34 & 46 & 63 & 36 & 54 & 59 & 43 & 31 \\
\hline
\end{tabular}

Keterangan: $(+)=$ ada, $(+)=$ hanya ada di satu wilayah, $(+)=$ ada di semua wilayah

Berdasarkan Tabel 4 tersebut, maka kontribusi spesies mangrove yang terdapat di pesisir Kabupaten Muna Barat adalah $15.87 \%$ terhadap total spesies mangrove di Sulawesi dan $10.20 \%$ terhadap total spesies mangrove di Indonesia. Dari total 98 spesies mangrove yang ditemukan, wilayah Sulawesi, Jawa, dan Kalimantan memberikan kontribusi yang besar terhadap total spesies mangrove di Indonesia yaitu 64.29\% (63 spesies) untuk Sulawesi, 60.20\% (59 spesies) untuk Jawa dan 55.10\% (54 spesies) untuk Kalimantan, sedangkan wilayah dengan kontribusi spesies terendah adalah Riau dengan nilai 31.63\% (31 spesies) (Gambar $3)$.

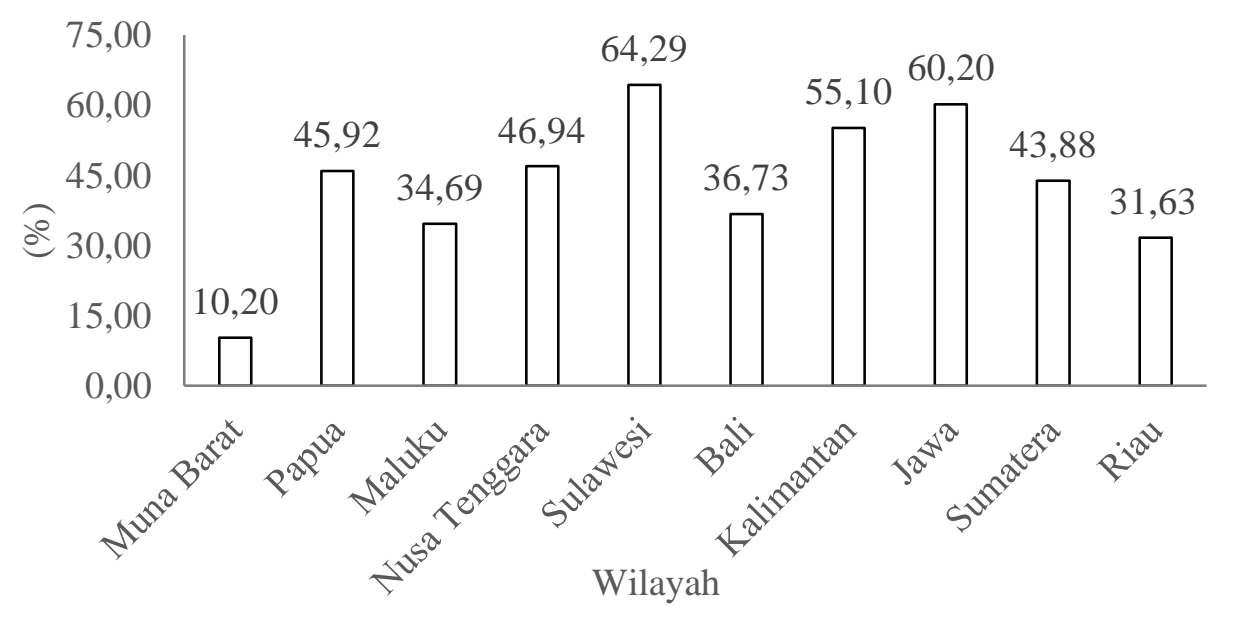

Gambar 3 Persentase perbandingan jumlah spesies tiap wilayah terhadap total spesies yang ditemukan di Indonesia

\section{Status Kerapatan Mangrove}

Tabel 5 menunjukkan bahwa secara umum status kerapatan mangrove di pesisir Kabupaten Muna Barat pada stasiun I, II, III, dan IV berada pada kriteria rendah dengan kerapatan masing-masing 879 pohon/ha, 621 pohon/ha, 688 pohon/ha, dan 821 pohon/ha, dengan total rata-rata yaitu 750 pohon/ha. Adapun kerapatan mangrove kategori semai yaitu 1800 individu/ha dengan kontribusi terbesar adalah spesies R.stylosa dan $R$. 
apiculata dengan nilai 514 individu/ha dan 333 individu/ha. Spesies yang dominan pada masing-masing stasiun adalah $R$. stylosa dan $S$. alba dan terendah adalah $X$. granatum dan $C$. inophyllum. Nilai kerapatan tersebut lebih rendah dibandingkan laporan Rahman et al. (2014) pada lokasi yang sama yaitu mencapai 1605 pohon/ha dan berada pada kategori tinggi (Rahman et al., 2019). Penurunan kerapatan mangrove disebabkan oleh alih fungsi lahan menjadi tambak yang dilakukan pada tahun 2016 hingga 2017, pemukiman, serta penggunaan kayu sebagai bahan bangunan (Rahman et al., 2020). Lebih lanjut, menurut Oni et al. (2019) untuk meningkatkan kerapatan vegetasi mangrove dapat dilakukan dengan rehabilitasi yang ditunjang oleh partisipasi masyarakat dengan menerapkan manajemen kolaboratif antara pemerintah, swasta, dan lembaga nirlaba.

Tabel 5 Nilai kerapatan mangrove di pesisir Kabupaten Muna Barat

\begin{tabular}{|c|c|c|c|c|c|c|c|c|c|c|}
\hline \multirow[b]{2}{*}{ Spesies } & \multicolumn{5}{|c|}{ Kerapatan pohon (pohon/ha) } & \multicolumn{5}{|c|}{ Kerapatan semai (ind/ha) } \\
\hline & Stasiun I & Stasiun II & Stasiun III & Stasiun IV & Rerata & $\begin{array}{c}\text { Stasiun } \\
\text { I }\end{array}$ & $\begin{array}{c}\text { Stasiun } \\
\text { II }\end{array}$ & $\begin{array}{c}\text { Stasiun } \\
\text { III }\end{array}$ & $\begin{array}{c}\text { Stasiun } \\
\text { IV }\end{array}$ & Rerata \\
\hline B. cylindrical & 93 & 38 & 34 & 7 & 43 & 330 & 166 & 67 & 37 & 150 \\
\hline B. gymnorrhiza & 105 & 59 & 34 & 32 & 57 & 467 & 133 & 154 & 87 & 210 \\
\hline R. apiculata & 180 & 106 & 144 & 75 & 126 & 667 & 267 & 224 & 179 & 333 \\
\hline R. mucronata & 120 & 74 & 121 & 65 & 95 & 543 & 189 & 216 & 155 & 276 \\
\hline R. stylosa & 225 & 178 & 137 & 282 & 205 & 736 & 427 & 312 & 584 & 514 \\
\hline S. alba & 156 & 162 & 218 & 302 & 209 & 412 & 315 & 448 & 512 & 317 \\
\hline$X$. granatum & 0 & 4 & 0 & 0 & 1 & 0 & 0 & 0 & 0 & 0 \\
\hline C. tagal & 0 & 0 & 0 & 25 & 6 & 0 & 0 & 0 & 0 & 0 \\
\hline S. hydrophyllacea & 0 & 0 & 0 & 28 & 7 & 0 & 0 & 0 & 0 & 0 \\
\hline C. inophyllum & 0 & 0 & 0 & 5 & 1 & 0 & 0 & 0 & 0 & 0 \\
\hline Total & 879 & 621 & 688 & 821 & 750 & 3155 & 1497 & 1421 & 1554 & 1800 \\
\hline
\end{tabular}

Keterangan: $B c=B$. cylindrica, $B g=B$. gymnorrhiza, $R a=R$. apiculata, $R$. mucronata, $R$. stylosa, $R s=S$. alba, $\mathrm{Xg}=X$. granatum, C.tagal, $\mathrm{Sh}=\mathrm{S}$. hydrophyllacea, $\mathrm{C} i=C$. inophyllum, dan KR, FR, DR dalam persen $(\%)$

\section{KESIMPULAN}

Jumlah spesies mangrove yang ada di pesisir Kabupaten Muna Barat adalah sepuluh spesies yang terdiri atas B. cylindrica, B. gymnorrhiza, $R$. mucronata, $R$. apiculata, $R$. stylosa, S. alba, X. granatum, C. tagal, $S$. hydrophyllacea, dan C. inophyllum. Total kerapatan mangrove adalah 752 pohon/ha yang terdiri atas 879 pohon/ha pada stasiun I, 621 pohon/ha pada stasiun II, 687 pohon/ha pada stasiun III, dan 820 pohon/ha pada stasiun IV dengan status kerapatan termasuk pada kategori rendah. Kerapatan ini mengalami penurunan akibat alih fungsi lahan menjadi tambak yang dilakukan pada tahun 2016 hingga 2017. Adapun kerapatan mangrove kategori semai yaitu 1800 individu/ha dengan kontribusi terbesar adalah spesies $R$. stylosa dan $R$. apiculata dengan nilai 514 individu/ha dan 333 individu/ha.

Lebih lanjut, hasil analisis terhadap INP pada tiap spesies mangrove menunjukkan bahwa spesies $R$. apiculata memiliki nilai INP terbesar pada stasiun I, II, dan III dengan nilai masing-masing yaitu 63.69\%, $60.28 \%$, dan $69.17 \%$, sedangkan yang terendah adalah C. inophyllum, X. granatum, S. hydrophyllacea, dan $C$. tagal dengan kisaran nilai secara umum yaitu 0 hingga $1.42 \%$ pada stasiun I sampai dengan III. Adapun spesies dengan nilai INP terbesar dan terkecil pada stasiun IV yaitu $S$. alba dan X. granatum dengan nilai masingmasing yaitu $92.62 \%$ dan $0 \%$. 


\section{UCAPAN TERIMA KASIH}

Penulis mengucapkan terima kasih kepada Lembaga Pengelola Dana Pendidikan (LPDP) Kementerian Keuangan Republik Indonesia selaku pemberi dana sehingga penelitian ini dapat terlaksana dengan baik dan lancar. Ucapan terima kasih juga saya haturkan kepada teman-teman yang telah membantu selama proses pengambilan data di lapangan.

\section{DAFTAR PUSTAKA}

Abo M, Banilodu L, Eduk EJ. 2015. Struktur Vertikal Komunitas Mangrove di Pesisir, Kupang Tengah, Kupang. Kupang (ID): Research Report of Widya Mandira Catholic University.

Abrantes K, Sheaves M. 2009. Food web structure in a near-pristine mangrove area of the Australia Wet Tropics. Estuarine, Coastal, and Shelf Science. 82(4): 597-607.

Abubakar S, Kadir MA, Wibowo ES, Akbar N. 2019. Manfaat mangrove bagi peruntukan sediaan farmasitika di Desa Mamuya Kecamatan Galela Timur Kabupaten Halmahera Timur (tinjauan etnofarmakologis). Jurnal Enggano. 4(1): 12-25.

Acik R, Sudarmadji. 2017. Hubungan antara faktor ekologi terhadap struktur komunitas mangrove di Teluk Pangpang Taman Nasional Alas Purwo. J of Basic Science. 18(1): 61-64.

Afkar, Djufri, Ali MS. 2014. Asosiasi makrozoobenthos dengan ekosistem mangrove di Sungai Reuleng Leupung, Kabupaten Aceh Besar. Jurnal Edubio Tropika. 2(2): 210-215.

Agustianingsih FD. 2006. Struktur komunitas kepiting pada ekosistem mangrove, hutan lindung di Angke Kapuk, Jakarta [tesis]. Bogor (ID): Institut Pertanian Bogor.

Agustini NT, Ta'alidin Z, Purnama D. 2016. Struktur komunitas mangrove di Desa Kahyapu Pulau Enggano. Jurnal Enggano. 1(1): 19-31.

Ahmad F. 2015. Kondisi hutan mangrove Teluk Piru, Seram Barat, Maluku. Jurnal Ilmu dan Teknologi Kelautan Tropis. 7(2): 731-743.

Akbar N, Baksir A, Tahir I. 2015. Struktur komunitas mangrove di kawasan pesisir Sidongali Kabupaten Halmahera Barat, Maluku Utara. Jurnal Depik. 4(3): 132-143.

Akbar N, Baksir A, Tahir I, Arafat D. 2016. Struktur komunitas mangrove di Pulau Mare, Kota Tidore Kepulauan, Maluku Utara, Indonesia. Jurnal Depik. 5(3): 133-142.

Akbar N, Marus I, Haji I, Abdullah S, Umalekhoa S, Ibrahim FS, Ahmad M, Ibrahim A, Kahar A, Tahir I. 2017. Struktur komunitas hutan mangrove di Teluk Dodinga, Kabupaten Halmahera Barat Provinsi Maluku Utara. Jurnal Enggano. 2(1): 78-89.

Akbar N, Ibrahim A, Haji I, Tahir I, Ismail F, Ahmad M, Kotta R. 2018. Struktur komunitas mangrove di desa Tewe, Kecamatan Jailolo Selatan, Kabupaten Halmahera Barat, Provinsi Maluku Utara. Jurnal Enggano. 3(1): 81-97.

Akhrianti I, Nurtjahya E, Franto, Syari IA. 2019. Kondisi komunitas mangrove di pesisir utara Pulau Mendanau dan Pulau Batu Dinding, Kabupaten Belitung. Jurnal Sumberdaya Perairan. 13(1): 12-26.

Ali M, Sulistiono, Imran Z. 2018. Mangrove vegetation: composition and structure in Bengawan Solo estuary, Indonesia. Naresuan University Journal: Science and Technology. 26(4): 107-118.

Alwi D, Koroy K, Laba E. 2019. Struktur komunitas ekosistem mangrove di Desa Daruba Pantai Kabupaten Pulau Morotai. Jurnal Ilmiah Wahana Pendidikan 5(4): 33-46.

Amaliyah R. 2017. Pengembangan aktivitas ekowisata mangrove berbasis konservasi di Kota Pekalongan, Jawa Tengah [tesis]. Bogor (ID): Institut Pertanian Bogor.

Andika IBMB, Kusmana C, Nurjaya IW. 2019. Dampak pembangunan jalan tol Bali Mandara terhadap ekosistem mangrove di Teluk Benoa Bali. Jurnal Pengelolaan dan Sumberdaya Lingkungan. 9(3): 641657. doi: http://dx.doi.org/10.29244/jpsl.9.3.641-657. 
Annisa R, Priosambodo D, Salam MA, Santosa S. 2017. Struktur komunitas mangrove asosiasi di sekitar area tambak Desa Balandatu Kepulauan Tanakeke Kabupaten Takalar Sulawesi Selatan. Jurnal Biologi Makassar. 2(1): 21-35.

Anthoni A, Schaduw JNW, Sondak CFA. 2017. Persentase tutupan dan struktur komunitas mangrove di sepanjang pesisir Taman Nasional Bunaken bagian utara. Jurnal Pesisir dan Laut Tropis. 2(1): 13-21.

Anwar H, Mertha IG. 2017. Komposisi jenis mangrove di teluk Gerupuk Kabupaten Lombok Tengah. Jurnal Sangkareang Mataram. 3(2): 25-31.

Ardiansyah WI, Pribadi R, Nirwani S. 2012. Struktur dan komposisi vegetasi mangrove pada zona pesisir Pulau Sebatik, Kabupaten Nunukan. Kalimantan Timur. J of Marine Research. 1(2): 203-215.

Arifin A. 2017. Struktur vegetasi mangrove berdasarkan substrat di Pantai Mara'Bombang Kecamatan Suppa Kabupaten Pinrang [skripsi]. Makassar (ID): Universitas Hasanuddin.

Ashari DP, Muhammad F, Utami S. 2019. Struktur komunitas hutan mangrove di Sungai Donan Kabupaten Cilacap, Jawa Tengah. Bioma. 21(1): 65-71.

Auliyah N, Blongkod A. 2018. Struktur komunitas mangrove di pesisir Desa Dalapuli Barat, Bolaang Mongondow Utara. Gorontalo Fisheries Journal. 1(1): 1-11.

Awn MS. 2017. Estimation of biomass and litter leaves productivity of mangrove for management in Enggano Island, Bengkulu, Sumatera, Indonesia [tesis]. Bogor (ID): IPB University.

Baderan DWK. 2016. Keanekaragaman jenis tumbuhan mangrove di kawasan pesisir Tabulo Selatan, Kabupaten Bualemo, Provinsi Gorontalo. Prosiding Seminar Nasional Lahan Basah. 1: 41-44.

Baderan DWK. 2017. Distribusi spasial dan luas kerusakan hutan mangrove di wilayah pesisir Kwandang Kabupaten Gorontalo Utara Provinsi Gorontalo. Jurnal GeoEco. 3(1): 1-8.

Baderan DWK. 2019. Struktur vegetasi dan zonasi mangrove di wilayah pesisir Kecamatan Kwandang Kabupaten Gorontalo Utara Provinsi Gorontalo. Bioma: Jurnal Biologi Makassar. 4(1): 20-30.

Baksir A, Akbar N, Tahir I, Haji I, Ahmad M, Kotta R. 2018. Struktur komunitas hutan mangrove di Pulau Sibu Kota Tidore Kepulauan Provinsi Maluku Utara. Jurnal Enggano. 3(2): 178-196.

Bengen DG. 2004. Guidelines of Introducing and Management of Mangrove Ecosystem. Bogor (ID): CCRMSIPB University.

Bessie DM, Schaduw JN, Reppie E, Lasut MT. 2013. Community structure of mangrove at Marine Tourism Park of Kubang Bay, East Nusa Tenggara. Aquatic Science and Management, Edisi Khusus. 1: 3-9.

Buwono YR. 2017. Identifikasi dan kerapatan ekosistem mangrove di kawasan Teluk Pangpang Kabupaten Banyuwangi. Jurnal Ilmu Perikanan. 8(1): 32-37.

Buwono YR, Ardhana IPG, Sudarma M. 2015. Potensi fauna akuatik ekosistem hutan mangrove di kawasan Teluk Pangpang Kabupaten Banyuwangi. Ecotrophic. 9(2): 28-33.

Cahyanto T, Kuraesin R. 2013. Struktur vegetasi mangrove di Pantai Muara Marunda Kota Administrasi Jakarta Utara Provinsi DKI Jakarta. Edisi Spesial. 7(2): 73-88.

Danipranata J, Nurjaya IW, Damar A. 2019. Indeks kepekaan lingkungan di ekosistem mangrove menggunakan analisis citra satelit: studi kasus di Pesisir Barat Pulau Bangka, Propinsi Kepulauan Bangka Belitung. JPSL. 9(1): 75-85. doi: 10.29244/jpsl.9.1.75-85.

Darmadi AAK, Ardhana IPG. 2010. Komposisi spesies mangrove pada hutan mangrove Ngurah Rai Desa Pemogan, Kecamatan Denpasar Selatan, Kota Denpasar, Provinsi Bali. J of Basic Scince. 11(2): 167171.

Darmadi, Lewaru MW, Khan AMA. 2012. Struktur komunitas vegetasi mangrove berdasarkan karakter substrat di estuari Harmin Desa Cangkring, Kecamatan Cantigi, Kabupaten Indramayu. Jurnal Perikanan dan Kelautan. 3(3): 347-358.

Fakhrurrozy. 2015. Vegetasi mangrove di Pulau Sangihe dan Talaud Sulawesi Utara [tesis]. Jakarta (ID): Universitas Negeri Islam Syarif Hidayatullah.

Febriansyah, Hartono D, Negara BFSP, Renta PP, Sari YP. 2018. Struktur komunitas hutan mangrovdi Pulau Baai, Kota Bengkulu. Jurnal Enggano. 3(1): 112-128. 
Fuady I, Pribadi R, Nirwani. 2013. Struktur komunitas mangrove di pulau Mejala, Kabupaten Kepulauan Anambas, dan Pulau Liran Kabupaten Maluku Tenggara. Journal of Marine Research 2(2): 94-102.

Ghufrona RR, Kusmana C, Rusdiana O. 2015. Komposisi jenis dan struktur komunitas hutan mangrove di Pulau Sebuku, Kalimantan Selatan. Jurnal Silvikultur Tropika. 6(1): 15-26.

Haerul. 2016. Analisis factor-faktor yang mempengaruhi efektivitas pengelolaan ekosistem mangrove berbasis masyarakat (studi kasus pesisir Kabupaten Pangkep, Provinsi Sulawesi Selatan) [tesis]. Bogor (ID): Institut Pertanian Bogor.

Halawa S, Kamal E, Suardi ML. 2013. Struktur komposisi mangrove di zona pesisir Teluk Dalam Kabupaten Nias Selatan, Provinsi Sumatera Utara. e-journal Universitas Bung Hatta. 1-12.

Hamidi R, Sastrodihardjo S, Adianto, Taufikurahman. 2002. Struktur komunitas dan produksi serasah mangrove di Dumai, Riau. Biologi. 2(13): 755-767.

Hamuna B, Tanjung RHR. 2018. Deteksi perubahan luasan mangrove Teluk Youtefa Kota Jayapura menggunakan citra landsat multitemporal. Majalah Geografi Indonesia. 32(2): 115-122.

Hanggara BB. 2016. Laju sedimentasi dan akumulasi sedimen tanah hutan mangrove di Kabupaten Deli Serdang, Sumatera Utara [skripsi]. Bogor (ID): Institut Pertanian Bogor.

Hartati, Harudu L. 2016. Identifikasi jenis-jenis kerusakan ekosistem hutan mangrove akibat aktivitas manusia di Kelurahan Lowu-lowu Kecamatan Lea-lea Kota Bau-bau. Jurnal Penelitian Pendidikan Geografi. 1(1): 30-45.

Hastuti ED, Anggoro S, Pribadi R. 2013. Pengaruh spesies dan kerapatan mangrove terhadap kandungan Cd dan $\mathrm{Cr}$ sedimen di wilayah pesisir Semarang dan Demak. Proceeding of National Seminar of Resourches and Environmental Management. 331-336.

Haya N, Zamani NP, Soedharma D. 2015. Analisis komunitas ekosistem mangrove di desa Pulau Joronga, Kabupaten Kukupang. J of Fisheries and Marine Technology. 6(1): 79-89.

Hermawan AR, Pribadi R, Ario R. 2015. Struktur dan komposisi vegetasi mangrove alami di taman ekowisata hutan mangrove Ngurah Rai, Bali. J of Marine Research. 3(4): 405-414.

Hidayatullah M, Pujiono E. 2014. Struktur dan komposisi jenis hutan mangrove di Golo Sepang Kecamatan Boleng Kabupaten Manggarai Barat. Jurnal Penelitian Kehutanan Wallacea. 3(2): 151-162.

Hilmi E, Siregar AS, Febriyanni L, Novaliani R, Amir SA, Syakti AD. 2015. Struktur komunitas, zonasi dan keragaman vegetasi mangrove di Segara Anakan, Cilacap. Omni-Akuatika. 11(2): 20-32.

Hogarth PJ. 2007. The Biologis of Mangroves and Seagrasses. America (US): Oxford University Press.

Idrus S. 2016. Inisiasi pemberdayaan jasa lingkungan untuk kelestarian fungsi ekologi hutan mangrove di Kecamatan Jailolo Kabupaten Halmahera Barat [tesis]. Bogor (ID): Institut Pertanian Bogor.

Imamsyah A. 2017. Struktur dan distribusi vegetasi mangrove di Taman Hutan Ngurai Rai, Bali [tesis]. Bogor (ID): Institut Pertanian Bogor.

Imanuddin, Simarangkir BDAS. 2012. Analisis vegetasi hutan mangrove di Teluk Pangempang Kecamatan Muara Badak, Kabupaten Kutai Kertanegara. J of Humida Tropical Forest. 5(1): 15-24.

Imran A, Efendi I. 2016. Inventarisasi mangrove di pesisir Pantai Cemara Lombok Barat. JUPE. 1(1): 105112.

Irma W, Atmaja AT, Marfa'i MA. 2020. Biodiversitas vegetasi mangrove di Kecamatan Concong Kabupaten Indragiri Hilir Provinsi Riau. Biosfera a Scientific Journals 37(2): 12-20.

Irpan FB, Manurung TF, Muflihati. 2017. Komposisi dan struktur vegetasi penyusun zonasi hutan mangrove Tanjung Prapat Muda - Tanjung Bakau Kabupaten Kubu Raya. Jurnal Hutan Lestari. 5(1): 104-112.

Irwansah, Sugiyarto, Mahajoeno E. 2019. Struktur komunitas ekosistem mangrove di Teluk Serewe Pulau Lombok Nusa Tenggara Barat. Bioeksperimen. 5(2): 126-130.

Jacobs R, Kusen JD, Sondak CFA, Boneka FB, Worouw V, Mingkid WM. 2019. Struktur komunitas ekosistem mangrove dan kepiting bakau di Desa Lamanggo dan Desa Tope, Kecamatan Biaro, Kabupaten Kepulauan Siau, Tagulandang Biaro. Jurnal Pesisir dan Laut Tropis. 1(1): 20-28. 
Jamili, Setiadi D, Qayim I, Guhardja E. 2009. Struktur dan komposis mangrove di Pulau Kaledupa Taman Nasional Wakatobi, Sulawesi Tenggara. Marine Science. 14(4): 197-206.

Karnanda M, Muchlisin ZA, Sarong MA. 2016. Struktur komunitas mangrove dan strategi pengelolaannya di Kecamatan Pidie, Provinsi Aceh, Indonesia. Depik. 5(3): 113-127.

Kathiresan K, Bingham BL. 2001. Biology of Mangroves and Mangrove Ecosystems. Cambridge (US): Academic Press.

Katiandagho B. 2015. Analisis struktur dan status ekosistem mangrove di Perairan Timur Kabupaten Biak Numfor. J Agrikan. 8(1): 8-12.

Kaunang TD, Kimbal JD. 2009. Analisis komposisi dan struktur hutan mangrove di Taman Nasional Bunaken, Sulawesi Utara. Argitek. 17(6): 1163-1171.

Khairuddin B. 2016. Strategi pengelolaan ekosistem mangrove yang terpadu dan berkelanjutan di Kabupaten Mempawah Provinsi Kalimantan Barat [tesis]. Bogor (ID): Institut Pertanian Bogor.

Kontu T. 2014. Struktur komunitas mangrove Batuline Desa Bahoi Kecamatan Likupang Barat Kabupaten Minahasa Utara. J of Coastal and Marine Tropical. 1(1): 24-29.

Kuncoro I, Arotonang AB, Helena S. 2019. Analisis vegetasi mangrove di Muara Sungai Peniti, Kabupaten Mempawah. Jurnal Laut Khatulistiwa. 2(1): 32-38.

Kusiani H, Sukanto. 2015. Teknik pengamatan vegetasi mangrove di pesisir Kabupaten Pangandaran, Jawa Barat. BTL. 13(2): 83-90.

Kusmana C. 1997. Metode Survei Vegetasi. Bogor (ID): IPB Press.

Kusmana C, Onrizal, Sudarmadji. 2003. Jenis - Jenis Mangrove di Teluk Bintuni Papua. Bogor (ID): Institut Pertanian Bogor.

Kusmana C, Ningrum DRP. 2016. Tipologi dan kondisi vegetasi kawasan mangrove Bulaksetra Kabupaten Pangandaran Provinsi Jawa Barat. Jurnal Silvikultur Tropika. 7(2): 137-145.

Lapa L, Santoso D. 2019. Analisis komunitas mangrove di Kecamatan Sekotong Lombok Barat NTB. Jurnal Biologi Tropis. 19(1): 25-33.

Ledheng L, Ardhana IPG, Sundra IK. 2009. Komposisi dan struktur vegetasi mangrove di Pantai Tanjung Bastian, Kabupaten Timor Tengah Utara, Provinsi Nusa Tenggara Timur. Ecotrophic. (4)2: 80-85.

Lewerissa YA, Sangaji M, Latumahina MB. 2018. Pengelolaan mangrove berdasarkan tipe substrat di perairan Negeri Ihamahu Pulau Saparua. Jurnal Triton. 14(1): 1-9.

Lisna, Malik A, Toknok B. 2017. Potensi vegetasi hutan mangrove di wilayah pesisir pantai Desa Khatulistiwa Kecamatan Tinombo Selatan Kabupaten Parigi Moutong. Warta Rimba. 5(1): 63-70.

Madiama S, Muryani C, Santoso S. 2016. Kajian perubahan luas dan pemanfaatan serta persepsi masyarakat terhadap pelestarian hutan mangrove di Kecamatan Teluk Ambon Baguala. Jurnal GeoEco. 2(2): 170183.

Malik M. 2011. Evaluasi komposisi dan struktur vegetasi mangrove di kawasan pesisir Kecamatan Tugu, Kota Semarang [tesis]. Semarang (ID): Universitas Negeri Semarang.

Marcus J, Latupapua J. 2015. Struktur dan vegetasi hutan mangrove di Desa Tagalaya, Kabupaten Halmahera Utara. J Agroforestri. 10(2): 155-163.

Mariati W. 2016. Pengembangan ekowisata di kawasan mangrove Desa Anak Setatah Kabupaten Kepulauan Meranti Provinsi Riau [tesis]. Bogor (ID): Institut Pertanian Bogor.

Marini, Kushadiwijayanto AA, Nurrahman YA. 2018. Struktur komunitas hutan mangrove di Desa Bakau Kecil Kabupaten Mempawah Kalimantan Barat. Jurnal Laut Khatulistiwa. 1(3): 73-80.

Martuti NKT. 2017. Keanekaragaman mangrove di wilayah tapak, Tugurejo Semarang. Jurnal MIPA. 36(2): 123-130.

Martuti NKT, Hidayah I, Margunani. 2018. The role of mangroves in the development of Batik in the coast of Semarang City. National Seminar Proceeding of Conservation and Using of Natural Diversity to National Welfare. 45-52. 
Masiyah S, Sunarni. 2015. Komposisi jenis dan kerapatan mangrove di Pesisir Arafura Kabupaten Merauke Provinis Papua. Jurnal Ilmiah Agribisnis dan Perikanan. 8(1): 60-69.

Mayor T, Simbala HEI, Koneri R. 2017. Keragaman mangrove di Pulau Mansuar Kabupaten Raja Ampat Provinsi Papua Barat. J of Bioslogos. 7(2): 41-48.

Meidiana V, Apriansyah, Safitri I. 2019. Struktur komunitas dan estimasi karbon sedimen mangrove di Desa Sebubus Kabupaten Sambas Kalimantan Barat. Jurnal Laut Khatulistiwa. 2(3): 107-117.

Mendrofa S. 2017. Potensi dan strategi pengelolaan ekosistem mangrove di Kecamatan Sawo, Kabupaten Nias Utara, Provinsi Sumatera Utara [tesis]. Bogor (ID): Institut Pertanian Bogor.

Momo LH, Rahayu WS. 2018. Analisis vegetasi hutan mangrove di Desa Wambona Kecamatan Wakorumba Selatan, Kabupaten Muna, Indonesia. Jurnal Akuakultur, Pesisir dan Pulau-pulau Kecil. 2(1): 10-16.

Mughofar A, Masykuri M, Setyono P. 2018. Zonasi dan komposisi hutan mangrove di Pantai Cengkrong Desa Karanggandu Kabupaten Trenggalek Propinsi Jawa Timur. Jurnal Pengelolaan Sumberdaya Alam dan Lingkungan. 8(1): 77-85.

Muharamsyah S, Anwari MS, Ardian H. 2019. Keanekaragaman jenis mangrove di Desa Mendalok Kecamatan Sungai Kunyit Kabupaten Mempawah. Jurnal Hutan Lestari. 7(1): 189-197.

Mukhlisi, Hendrarto IB, Purnaweni H. 2014. Keanekaragaman jenis dan struktur vegetasi mangrove di Desa Sidodadi Kecamatan Padang Cermin Kabupaten Pesawaran, Provinsi Lampung. Jurnal Geografi. 11(1): $58-70$.

Nauw FH. 2012. Komposisi dan struktur vegetasi hutan mangrove di Desa Kumu Kecamatan Tombariri Kabupaten Minahasa. Cocos. 1(1): 1-20.

Noor YR, Khazali M, Suryadiputra INN. 2006. Panduan Pengenalan Mangrove di Indonesia. Bogor (ID): Wetlands International-Indonesia Programme.

Nopiana M, Yulianda F, Sulistiono, Fahrudin A. 2020. Condition of shore and mangrove area in the coastal area of Karawang Regency, Indonesia. AACL Bioflux. 13(2): 553-569.

Nordhaus I, Wolff M., Diele K. 2006. Litter processing and food intake of the mangrove crab Ucides cordatus in a high intertidal forest in northen Brazil. Estuarine, Coastal, and Shelf Science. 67(1-2): 239 -250.

Noveliyana Y. 2016. Pengelolaan ekosistem mangrove berkelanjutan di pesisir Kabupaten Tanggerang, Provinsi Banten [tesis]. Bogor (ID): Institut Pertanian Bogor.

Nurrahman YA, Djunaedi OS, Rostika R. 2012. Struktur dan komposisi vegetasi mangrove di Pesisir Kecamatan Sungai Raya Kabupaten Bengakayang Kalimantan Barat. J of Fisheries and Marine. 3(1): 99-107.

Oni, Kusmana C, Basuni S. 2019. Succes story rehabilitasi ekosistem mangrove di Pantai Karangsong Kabupaten Indramayu. JPSL. 9(3): 447-487. doi: http://dx.doi.org/10.29244/jps1.9.3.477-487.

Osmar M. 2016. Studi analisis komposisi dan struktur tegakan hutan mangrove di Desa Tanjung Bunga Kabupaten Konawe Utara [tesis]. Kendari (ID): Universitas Halu Oleo.

Palguna IBA, Ardhana IPG, Arthana IW. 2017. Struktur dan keanekaragaman jenis mangrove di Kawasan Hutan Mangrove Nusa Lembongan, Kecamatan Nusa Penida, Kabupaten Klungkung. Ecothropic. 11(2): 108-115.

Parmadi EHJC, Dewiyanti I, Karina S. 2016. Indeks nilai penting vegetasi mangrove di kawasan Kuala IDI, Kabupaten Aceh Timur. Jurnal Ilmiah Mahasiswa Kelautan dan Perikanan Unsyiah. 1(1): 82-95.

Paruntu CP, Windarto AB, Rumengan AP. 2017. Karakteristik komunitas mangrove Desa Matondai Kecamatan Pinolosian Timur Kabupaten Bolaang Mongondow Selatan Provinsi Sulawesi Utara. Jurnal Pesisir dan Laut Tropis. 1(2): 53-65.

Poedjirahajoe E, Marsono D, Wardani FK. 2017. Penggunaan principal component analysis dalam distribusi spasial vegetasi mangrove di Pantai Utara Pemalang. Jurnal Ilmu Kehutanan. 11: 29-42.

Prastomo RH, Herawatingsih R, Latifah S. 2017. Keanekaragaman vegetasi di kawasan hutan mangrove Desa Nusapati Kabupaten Mempawah. Jurnal Hutan Lestari. 5(2): 556-562. 
Pratama SS. 2018. Analisis vegetasi mangrove di muara Desa Kurau Kecamatan Koba Kabupaten Bangka Tengah Provinsi Kepulauan Bangka Belitung [skripsi]. Palembang (ID): Universitas Islam Negeri Raden Fatah.

Pribadi R, Khakim A, Nurdianto F. 2017. Structure and composition of mangrove vegetation in Pantai Mekar and Pantai Harapan Jaya Village, District of Muara Gembong, Bekasi Regency, West Java Province. The $6^{\text {th }}$ Results of Fisheries and Marine Research of Diponegoro University. 819-828.

Purba R, Yandri F, Pratomo A. 2013. Struktur komunitas ekosistem mangrove di Pulau Poto Desa Kelong, Kecamatan Bintan Pesisir, Kabupaten Bintan, Provinsi Kepulauan Riau. Journal Univeritas Raja Ali Haji. 8: 1-9.

Puspita PPS. 2015. Konsep pengembangan ekoswisata mangrove berbasis masyarakat di Desa Pasar Banggi, Kabupaten Rembang [skripsi]. Bogor (ID): Institut Pertanian Bogor.

Putri L, Yulianda F, Wardiatno Y. 2015. Pola zonasi mangrove dan asosiasi makrozoobenthos di wilayah Pantai Indah Kapuk, Jakarta. Bonorowo Wetlands. 5(1): 29-43.

Putro ES, Tasirin JS, Lasut MT, Langi MA. 2013. Struktur dan komposisi vegetasi mangrove di Pulau Mantehage. Cocos. 6(5): 1-6.

Rachmawani D. 2007. Kajian pengelolaan ekosistem mangrove secara berkelanjutan Kota Tarakan Kalimantan Timur (studi kasus Desa Binalatung Kecamatan Tarakan Timur) [tesis]. Bogor (ID): Institut Pertanian Bogor.

Rahayu SM, Syuhriatin, Wiryanto. 2018. Keanekaragaman mangrove di Desa Gedangan, Kecamatan Purwodadi, Kabupaten Purworejo Jawa Tengah. Enviroscienteae. 14(1): 62-69.

Rahim S, Baderan DWK. 2019. Komposisi jenis, struktur komunitas, dan keanekaragaman mangrove asosiasi Langge Kabupaten Gorontalo Utara - provinsi Gorontalo. Jurnal Ilmu Lingkungan. 7(1): 181-188.

Rahim S, Baderan DWK, Hamidun MS. 2017. The density, composition and mangrove forest habitat in coastal area of Torosiaje Jaya Village, Gorontalo Indonesia. Bonorowo Wetlands. 7(1): 38-42.

Rahim S, Baderan DWK, Hamidun MS. 2018. Keanekaragaman spesies, biomassa dan stok karbon pada hutan mangrove Torosiaje Kabupaten Pohuwato-Provinsi Gorontalo. Jurnal Pro-Life. 5(3): 650-665.

Rahman, Efendi H, Rusmana I. 2017. Stock estimation and carbon absorpton of mangrove in Tallo River, Makassar. Journal of Forest Sicence. 11: 19-28.

Rahman, Wardiatno Y, Yulianda F, Rusmana I. 2020. Socio-ecologycal system of carbon-based mangrove ecosystem on the coast of West Muna Regency, Southeast Sulawesi, Indonesia. AACL Bioflux. 13(2): 518-528.

Rahman, Yanuarita D, Nurdin N. 2014. Struktur komunitas mangrove di Kabupaten Muna. Torani - $J$ of Marine Science and Fisheries. 24(2): 29-36.

Rahman, Yulianda F, Rusmana I, Wardiatno Y. 2019. Production ratio of seedlings and density status of mangrove ecosystem in coastal areas of Indonesia. Advances in Environmental Biology. 13(6): 13-20.

Ramdani D, Liviawaty E, Ihsan YN. 2015. Pengaruh perbedaan struktur komunitas mangrove terhadap konsentrasi N danP di perairan Hutan Garut Sancang. Fisheries Marine Journal. 6(2): 7-14.

Ratnasari, Fahrizal, Dirhamsyah M. 2017. Pemanfaatan vegetasi mangrove di Pulau Padang Tikar Kecamatan Batu Ampar Kabupaten Kubu Raya. Jurnal Tengkawang. 7(2): 110-115

Renta PP, Pribadi R, Zainuri M, Anggraini M, Utami F. 2016. Struktur komunitas mangrove di Desa Mojo Kabupaten Pemalang Jawa Tengah. Jurnal Enggano. 1(2): 1-10.

Rita RND. 2015. Analisis vegetasi dan struktur komunitas mangrove di Taman Bangko-Bangko Kabupaten Lombok Barat. Mataram Sangkareang Journal. 1(3): 46-50.

Rivilgo W, Tanjung A, Ghalib M. 2017. Struktur komunitas mangrove di perairan Desa Kuala Alam Kecamatan Bengkalis Kabupaten Bengkalis Provinsi Riau [skripsi]. Riau (ID): Universitas Riau.

Rizwany Y, Yunasfi, Muhtadi A. 2016. Struktur dan komposisi vegetasi mangrove di dusun II desa Pulau Sembilan, Kecamatan Pangkalan Susu, Kabupaten Langkat, Provinsi Sumatera Utara. $J$ of Aquacoastmarine. 13(3): 1-11. 
Rochmady. 2015. Struktur dan komposisi mangrove di Desa Bonea dan Kodiri, Kaabupaten Muna, Sulawesi Tenggara. Proceedings of Fisheries and Marine National Symposium Makassar. 85-94.

Rumalean AS, Purwanti F, Hendrarto B, Hutabarat S. 2019. Struktur komunitas hutan mangrove pada kawasan Mempawah Mangrove Park di Desa Pasir Mempawah Hilir. Jurnal Ilmu dan Teknologi Kelautan Tropis. 11(1): 221-230.

Rusydi, Ihwan, Suaedin. 2015. Struktur dan kerapatan vegetasi mangrove di teluk Kupang. J of Segara. 11(2): 147-157.

Saman RU. 2017. Keberlanjutan pengelolaan ekosistem mangrove di Kecamatan Bolaang Mongondow Selatan, Provinsi Sulawesi Utara [tesis]. Bogor (ID): Institut Pertanian Bogor.

Samsumarlin, Rachman I, Toknok B. 2015. Studi zonasi vegetasi mangrove muara di Desa Umbele Kecamatan Bumi Raya Kabupaten Morowali Sulawesi Tengah. Warta Rimba. 3(3): 148-154.

Sani LH, Candri DA, Ahyadi H, Farista B. 2019. Struktur vegetasi mangrove alami dan rehabilitasi pesisir selatan Pulau Lombok. Jurnal Biologi Tropis. 19(2): 268-276.

Saru A, Amri K, Mardi. 2017. Konektivitas struktur vegetasi mangrove dengan keasaman dan bahan organik total pada sedimen di Kecamatan Wonomulyo Kabupaten Polewali Mandar. Spermonde. 3(1): 1-6.

Saru A, Idrus R, Ilham M. 2019. The mangrove ecosystem potential for educational tour development around pond education of Hasanuddin Univeristy (UNHAS) in Mallusteasi District, Barru Regency. Jurnal Ilmu Kelautan Spermonde. 5(2): 70-76.

Sasauw J, Kusen JD, Schaduw JNW. 2016. Struktur komunitas mangrove di Desa Tongkaina, Manado. J of Coastal and Marine Tropical. 2(1): 17-22.

Schaduw JNW. 2019. Struktur komunitas dan persentase penutupan kanopi mangrove Pulau Sulawati Kabupaten Kepulauan Raja Ampat Provinsi Papua Barat. Majalah Geografi Indonesia. 33(1): 26-34.

Seran W. 2019. Struktur dan komposisi hutan mangrove di Pantai Paradiso, Kota Kupang NTT. Jurnal Agribisnis Perikanan. 12(1): 34-42.

Setiawan H, Mursidin. 2018. Karakteristik ekologi dan kesehatan hutan mangrove di Pulau Tanakeke Sulawesi Selatan. Jurnal Penelitian Kehutanan Wallacea. 7(1): 47-58.

Setyawan AD, Indrowiryatno, Wiryanto, Winarno K, Susilowati A. 2005. Tumbuhan mangrove di Pesisir Jawa Tengah: 1. keanekaragaman jenis. Biodiversitas. 6(2): 90-94.

Siringoringo YN, Djayus Y, Desrita. 2017. Struktur komunitas mangrove di hutan mangrove, Desa Belawan Sicanang, Kabupaten Medan Belawan, Provinsi Sumatera Utara. J of Aquacoastmarine. 5(2): 1-7.

Siska F. 2016. Produktivitas dan laju dekomposisi serasah Avicennia marina dan Rhizophora apiculata di Cagar Alam Pulau Dua Banten [tesis]. Bogor (ID): Institut Pertanian Bogor.

Sitinjak FN. 2017. Struktur komunitas hutan mangrove di Desa Mengkapan, Kecamatan Sungai Apit, Kabupaten Siak. [tesis]. Pekanbaru (ID): Riau University.

Sunarni, Maturbongs MR, Arifin T, Rahmania R. 2019. Zonasi dan struktur komunitas mangrove di pesisir Kabupaten Merauke. Jurnal Kelautan Nasional. 14(3): 165-178.

Supriadi, Romadhon A, Farid A. 2015. Struktur komunitas mangrove di Desa Martajasah Kabupaten Bangkalan. Marine Journal. 8(1): 44-51.

Suryono CA. 2006. Struktur populasi vegetasi mangrove di Laguna Segara Anakan Cilacap, Jawa Tengah. Ilmu Kelautan. 11(2): 112-118.

Susanto AH, Soedarti T, Purnobasuki H. 2013. Struktur komunitas mangrove di sekitar Jembatan Suramadu sisi Surabaya. Bioscientiae. 10(1): 1-10.

Susilo F. 2007. Pengelolaan ekosistem mamgrove di Kecamatan Percut Sei Tuan Kabupaten Deli Serdang, Sumatera Utara [tesis]. Bogor (ID): Institut Pertanian Bogor.

Suyadi. 2009. Kondisi hutan mangrove di Teluk Ambon: prospek dan tantangan. Berita Biologi. 9(5): 481490.

Syahrial. 2018. Keadaan hutan mangrove di utara Indonesia berdasarkan indikator kualitas lingkungan dan indikator ekologi komunitas. Maspari Journal. 10(1): 89-96. 
Syahrial, Bengen DG, Prartono T, Amin B. 2018. Struktur demografi populasi Rhizophora apiculata di kawasan industri perminyakan Provinsi Riau. Jurnal Perikanan Tropis. 5(2): 189-197.

Syahrial, Lubis MK, Pranata E, Hamdani R, Syahrian W, Purnama DP, Kaprisai, Hutasuhut MD. 2017. Variasi geografik kerapatan mangrove dan kepadatan gastropoda serta keterkaitannya di Pulau Tunda Serang Banten, Indonesia. Biowallacea. 4(2): 591-601.

Syahputra R, Yandri F, Koerniawan CJ. 2013. Struktur komunitas mangrove di Pulau Keter Tengah Kabupaten Bintan. E-Jurnal Universitas Martim Raja Ali Haji.1-7.

Syawala N. 2013. Komposisi vegetasi hutan mangrove di Desa Mogo, Kecamatan Ulujami, Kabupaten Pemalang, Provinsi Jawa Tengah [tesis]. Surakarta (ID): Muhammadiyah Surakarta University.

Tabba S, Wahyuni NI, Mokodompit HS. 2015. Komposisi dan struktur vegetasi mangrove tiwoho di kawasan Taman Nasional Bunaken. Jurnal Wasian. 2(2): 95-103.

Tahir I, Paembonan RE, Harahap ZA, Akbar N, Wibowo ES. 2017. Sebaran kondisi ekosistem hutan mangrove di kawasan Teluk Jailolo Kabupaten Halmahera Barat Provinsi Maluku Utara. Jurnal Enggano. 2(2): 143-155.

Tefarani R, Martuti NKT, Ngabekti S. 2019. Keanearagaman spesies mangrove dan zonasi di wilayah Kelurahan Mangunharjo Kecamatan Tugu Kota Semarang. Life Science. 8(1): 41-53.

Theresia. 2016. Pengelolaan ekosistem mangrove di Taman Nasional Sembilang Kabupaten Banyuasin Provinsi Sumatera Selatan [tesis]. Bogor (ID): Institut Pertanian Bogor.

Tolangara A, Ahmad H. 2017. Kerapatan mangrove dan konservasinya di Bacan Kabupaten Halmahera Selatan, Provinsi Maluku Utara. Techno. 6(2): 22-29.

Ula ED, Suhadi, Rohman F. 2016. Struktur komunitas mangrove di Desa Mangunharjo Kecamatan Mayangan, Kota Probolinggo. Proceedings of Biologi National Seminar. 96-102.

Usman L, Syamsuddin, Hamzah SN. 2013. Analisis vegetasi mangrove di Pulau Dudepo Kecamatan Anggrek Kabupaten Gorontalo Utara. Jurnal Ilmiah Perikanan dan Kelautan. 1(1): 11-17.

Wahyuningsih EP, Suleman SM, Ramadanil. 2012. Struktur dan komposisi vegetasi mangrove di Desa Lalombi Kecamatan Benawa Selatan Kabupaten Donggala. Biocelebes. 6(2): 84-100.

Wambrauw ET, Pattiasina TF. 2005. Struktur komunitas mangrove dan distribusinya pada pantai Wosidori Arfai Kabupaten Manokwari. J of Fisheries and Marine Scientific. 1(1): 1-11.

Wantoro, Syahdan M, Salim D. 2017. Struktur komunitas jenis mangrove di Kabupaten Tanah Laut Provinsi Kalimantan Selatan. Marine, Coastal and Small Islands Journal. 1(1): 2-10.

Warsidi, Endayani S. 2017. Komposisi vegetasi mangrove di Teluk Balikpapan Provinsi Kalimantan Timur. $J$ Argifor. 16(1): 115-124.

Wibisono G. 2013. Studi struktur komunitas dan komposisi vegetasi mangrove dan pengelolaannya di Desa Samkai Kabupaten Merauke [tesis]. Jakarta (ID): Indonesian Open University.

Wicaksono FB. 2014. Komposisi jenis pohon dan struktur tegakan hutan mangrove di Desa Pasarbanggi, Kabupaten Rembang, Jawa Tengah [tesis]. Bogor (ID): Institut Pertanian Bogor.

Wicaksono FB, Muhdin. 2015. Komposisi jenis pohon dan struktur tegakan hutan mangrove di Desa Pasarbanggi, Kabupaten Rembang, Jawa Tengah. Bonorowo Wetlands. 5(2): 55-62.

Witjaksono J. 2002. Struktur komunitas mangrove dan analisis finansial usaha pada lahan konversi hutan mangrove di pesisir Teluk Kendari [tesis]. Bogor (ID): IPB University.

Wiyanto DB, Faiqoh E. 2015. Analisis vegetasi dan struktur komunitas mangrove di Teluk Benoa, Bali. $J$ of Marine and Aquatic Science. 1: 1-7.

Woodroffe CD. 1982. Litter production and decomposition in the New Zealand mangrove, Avicennia marina var. resinifera, New Zealand Journal of marine and Freshwater research. 16(2): 170-188.

Yewen M, Mudjirahayu, Pattiasina TF, Bawole R. 2008. Struktur komunitas dan distribusi mangrove dan pengelolaannya di Kecamatan Teminabun, Kabupaten Sorong Selatan. Proceedings National Conference of Coastal and Marine Resourches Management. 305-319. 
Zamdial. 2016. Analisa struktur komunitas hutan mangrove di Desa Pasar Sebelah Kecamatan Kota Mukomuko Kabupaten Mukomuko. Jurnal Enggano. 1(2): 29-37.

Zamdial, Hartono D, Johan Y. 2019. Struktur komunitas ekosistem mangrove di kawasan pesisir kota Mukomuko Kabupaten Mukomuko Provinsi Bengkulu. Jurnal Enggano. 4(1): 92-104.

Zamroni Y. 2017. Ekologi mangrove di perairan Teluk Sepi Lombok Barat. Bio Wallacea. 3(2): 79-83. 